\title{
SOBRE O POTENCIAL TRANSFORMADOR DA EXPERIÊNCIA COM A LITERATURA JUNTO A ADOLESCENTES NO CONTEXTO ESCOLAR
}

\author{
Celina Diaferia ${ }^{1}$ \\ PUCSP E IPUSP - LipSiC \\ Luis Cláudio Figueiredo² \\ PUCSP \\ Marina F R Ribeiro ${ }^{3}$ \\ PUCSP E IPUSP - LipSic
}

\section{RESUMO}

A leitura, a escrita e as artes podem vir a proporcionar transformações da experiência do self, ampliando as possibilidades de interpretação da realidade, que se torna mais diversa, rica e complexa. Este artigo apresenta um trabalho na interface da literatura com a psicanálise de D. W. Winnicott, tendo ainda como referência ideias de Marion Milner. De modo a compreender como se dá o processo de elaboração da experiência vivida por meio da leitura mediada e criação de textos ficcionais, foram selecionados alguns episódios vividos junto a alunos de treze e quatorze anos na escola. A partir da apresentação de objetos culturais em propostas com a leitura e a escrita, o educador cria um ambiente de confiança, favorável ao gesto criativo dos jovens. Algumas experiências vividas junto a adolescentes no contexto escolar permitem ao leitor ver como as angústias podem ser elaboradas em produções criativas, desde que sejam ofertados aos jovens meios maleáveis aos quais eles possam imprimir seu estilo pessoal e pelos quais possam expressar sua singularidade.

Palavras-chave: literatura, psicanálise, teoria geral do cuidado, educação.

\footnotetext{
${ }^{1}$ Celina Diaferia - Psicóloga e Psicanalista, Mestre em Psicologia Clínica - PUC-SP, Colaboradora do Lipsic IP USP/PUC, Cel. 11993934563

2 Luis Cláudio Figueiredo - Psicanalista, professor livre docente aposentado IPUSP, professor PUCSP, membro do Círculo Psicanalítico do Rio de Janeiro. Autor de diversos livros e artigos em psicanálise.

${ }^{3}$ Marina F R Ribeiro - Psicanalista, Professora Doutora do IPUSP, autora de diversos livros e artigos psicanalíticos.
} 


\title{
ON THE TRANSFORMING POTENTIAL OF THE EXPERIENCE WITH LITERATURE WITH ADOLESCENTS IN THE SCHOOL CONTEXT
}

\begin{abstract}
Reading, writing and arts can provide transformation of self-experience, expanding the possibilities of interpreting reality, which becomes more diverse, rich and complex. This article aims to present a work in an interface of literature with the psychoanalysis of D. W. Winnicott, still having as reference Marion Milner's ideas. In order to understand the process of elaborating the experience through mediated reading and creation of fictional texts, some episodes practiced with students of thirteen and fourteen years old at school were selected. From the presentation of cultural objects in proposals with reading and writing, the educator creates an reliable environment, facilitating student's creative gesture. Some experiences lived with teenagers in the school context allow the reader to see how anxieties can be worked out in creative productions, offering young people pliable mediums on which they can impress their personal style and through which they can express their singularity.
\end{abstract}

Keywords: literature, psychoanalysis, general care theory, education.ee4

\section{Introdução}

[A humanização] é o processo que confirma no homem aqueles traços que reputamos essenciais, como o exercício da reflexão, a aquisição do saber, a boa disposição para com o próximo, o afinamento das emoções, a capacidade de penetrar nos problemas da vida, o senso da beleza, a percepção da complexidade do mundo e dos seres, o cultivo do humor. A literatura desenvolve em nós a quota de humanidade na medida em que nos torna mais compreensivos e abertos à natureza, à sociedade e ao semelhante.

Antonio Candido (1989, p.117)

Neste artigo iremos apresentar algumas ideias sobre como a leitura, a escrita e as artes podem vir a proporcionar experiências de transformação do sujeito, no sentido de ampliar possibilidades de interpretação da realidade, a fim de torná-la mais diversa, rica e complexa.

Considerando-se certa tendência a se trabalhar o conhecimento da língua e da literatura de maneira primordialmente funcional, podem ser pensadas maneiras de se resgatar o encantamento com a poesia e a ficção na escola?

Não raro, prevalecem no contexto escolar práticas de aferição de leitura que se restringem à localização de informações em um texto, ou à mera reprodução do conhecimento, sem que seja considerada a subjetividade e estimulada a capacidade criativa dos alunos. Além da leitura, a produção escrita também pode ser demasiadamente enrijecida por estruturas a serem reproduzidas pelos jovens em suas produções. A nosso ver, tais práticas de abordagem da leitura e da escrita não apenas dificultam a experiência estética, como afastam os jovens de um uso mais efetivo e criativo da linguagem, já que as situações propostas na escola costumam ser artificiais, simulacros da realidade, em que os alunos aparentemente aprendem a reproduzir aquilo que supõem que o professor espera deles. 
Considerando a maneira como os alunos costumam ficar preocupados com o desempenho em provas e resultados e pouco atentos ao processo vivido, fomos procurando criar estratégias que pudessem tornar mais significativa a experiência de contato com o campo estético, de modo a favorecer a produção escrita autoral, bem como as capacidades leitoras ${ }^{1}$.

É comum que a produção escrita na escola se restrinja a aluno e professor, sendo este o único interlocutor-avaliador. Assim, os alunos produzem os textos, o professor os corrige e os devolve, oferecendo-lhes poucas referências, ou mesmo nenhuma, para que compreendam o porquê da nota final. Com isso, o professor permanece firme em seu lugar de detentor de um conhecimento acerca do que seria uma boa produção, e os alunos são impedidos de se apropriar de seus próprios escritos, sem poder alcançar mais autonomia para buscar um melhor acabamento, de acordo com o gênero discursivo solicitado. ${ }^{2}$

De modo a nos contrapormos a uma prática escolar desvitalizada e que pouco favorece a criação de sentidos, tanto na experiência da leitura como da escrita, propomos a eles que escrevam considerando não apenas a leitura do professor, mas também de outros leitores em potencial - colegas, professores de outras disciplinas, pais ou qualquer um que tenha interesse. Em busca de compreender mais profundamente a transformação que acompanhamos no decorrer de um ano de trabalho com eles, nos deparamos com o pensamento de Marion Milner, que, como Winnicott, também era psicanalista membro do Grupo Independente (Middle Group) da Sociedade Britânica de Psicanálise. Assim como ela, costumamos lançar aos alunos, como um desafio, o que chamamos de "brincadeira séria" - e que Marion Milner denomina "brincadeira concentrada" - para ajudá-los a aprender, pela experiência, a usar a leitura e a escrita como formas de dar voz ao que sentem e pensam de modo criativo e autoral. Como afirma Milner, não se trata de qualquer tipo de brincadeira, mas sim de "uma em que se utilizem materiais especiais, de modo que a brincadeira funcione de verdade" (MILNER, 1991, p.14).

Marion Milner tinha interesse em compreender a relação entre o trabalho criativo e o brincar, o problema da simbolização (encontrar o familiar no não familiar) e os tipos diferentes de concentração. Apontou, como fatores impeditivos para a aprendizagem plena, a imposição de padrões, interferências e expectativas exageradas dos pais em relação ao desempenho escolar, como também um sentimento de que "as exigências adultas eram uma tentativa de fazê-la [uma aluna com dificuldades de aprendizagem] moldar-se a um padrão de personalidade completamente estranho à sua natureza" (MILNER, 1991, p. 16).

Tomando por base o pensamento de Milner, propomos atividades em que os alunos terão de confiar - de modo verdadeiro - no inconsciente, confiar no vazio, no branco, confiar naquilo que parece não estar ali. Propomos que considerem suas ideias, seus sonhos, suas fantasias e reafirmamos, ancorada no que nós mesmos aprendemos com eles, que, mesmo que ainda não se

Segundo Roxane Rojo, as capacidades leitoras são: "de decodificação, de compreensão, de apreciação e réplica do leitor em relação ao texto (interpretação e interação). Atualmente a leitura é vista como um ato de se colocar em relação a um discurso (texto) com outros discursos anteriores a ele, emaranhados nele e posteriores a ele, como possibilidades infinitas de réplicas, gerando novos discursos e textos. O discurso/texto é visto como um conjunto de sentidos e apreciações de valor das pessoas e coisas do mundo, dependentes do lugar social do autor e do leitor e da situação de interação entre eles - finalidades da leitura e da produção de texto, esfera social de comunicação em que o ato da leitura se dá. Ler na vida é escapar da literalidade dos textos e interpretá-los, colocando-os em relação com outros textos e discursos, de maneira situada na realidade social; é discutir com os textos, replicando e avaliando posições e ideologias que constituem seus sentidos; é, enfim, trazer o texto para a vida e colocá-lo em relação com ela". (Rojo,2004).

2 "O emprego da língua efetua-se em forma de enunciados (orais e escritos) concretos e únicos, proferidos pelos integrantes desse ou daquele campo da atividade humana. Esses enunciados refletem as condições específicas e as finalidades de cada referido campo não só por seu conteúdo (temático) e pelo estilo da linguagem, ou seja, pela seleção dos recursos lexicais, fraseológicos e gramaticais da língua mas, acima de tudo, por sua construção composicional.[...] Evidentemente, cada enunciado particular é individual, mas cada campo de utilização da língua elabora seu tipos relativamente estáveis de enunciados, os quais denominamos gêneros do discurso.". (BAKHTIN, 2003, p. 261-262) 
sintam capazes de se lançar a um projeto autoral, dentro de cada um há um universo em potencial no qual precisamos apostar. Sem essa confiança, as forças invisíveis internas não podem fazer seu trabalho, e permaneceríamos então cindidos, impossibilitados de integrar opostos ou dominados "pela falsa oposição entre os deuses da luz e das trevas..." (MILNER, 1991, p. 17).

Neste contexto, procuramos reapresentar, em nosso trabalho, a linguagem escrita de maneira que os alunos possam usá-la de modo criativo.

No cotidiano com os adolescentes, é possível perceber como as obras artísticas - contos, filmes, peças teatrais e poemas - são capazes de conter ou sustentar angústias, desejos e inquietações, curiosidades, temores... As histórias ajudam os jovens a nomear, entender, tolerar frustrações, lidar com elementos de sua vida corporal e mental. Este é, segundo Figueiredo (2009), um meio para sua transformação e crescimento emocional. Essa capacidade de transformação corresponde à capacidade de sonhar: "Nossas vidas podem se enriquecer a partir do contato com esses objetos de continência, que sonham por nós e nos ensinam a sonhar os conteúdos das fantasias inconscientes que, para dentro deles, projetamos" (idem, p.137).

Na prática cotidiana em sala de aula, com alunos adolescentes, buscamos criar situações em que a literatura, as artes, enfim, possibilitem a compreensão e nomeação das vivências emocionais, além da ampliação do campo subjetivo e da imaginação. Para tanto, no decorrer de um ano, desenvolvemos propostas que favoreçam a leitura de narrativas, filmes e poemas, a fim de que os jovens interpretem metáforas e deem sua contribuição criativa por meio de textos autorais.

Como também temos percebido uma crescente terceirização dos cuidados com os adolescentes para especialistas mais preocupados com diagnósticos do que com a escuta, como estamos propondo aqui, suspeitamos que haja uma demanda desses jovens alunos de um olhar atento, de um reconhecimento de suas capacidades e de um diálogo que os ajudaria a dar algum sentido e valor ao mundo. Sendo assim, entendemos que uma prática de cuidado importante dos educadores seja proteger as capacidades de reparação e de criação, às vezes danificadas, dar assistência e ensinar (novamente) a brincar, tratando os jovens como agentes de transformação, capazes de serem mais do que meros reprodutores, apostando na vida e na esperança de construção de algo que não parece imediatamente possível. Afinal, ser completamente obediente à realidade tal como ela é nos levaria inevitavelmente ao adoecimento, uma vez que a saúde está, segundo o psicanalista D. W. Winnicott (1975), no "viver criativo". ${ }^{3}$

Diante disso, surge a questão: como o professor pode levar adiante essa prática de cuidado junto a alunos adolescentes, que justamente por estarem nesse momento de suas trajetórias de vida tendem ao embate ou questionamento com os adultos?

Para respondê-la, retomamos um episódio em sala de aula: quando discutíamos a leitura de um livro de Rodrigo Lacerda intitulado "O Fazedor de Velhos", um romance de formação ${ }^{4}$ que

\footnotetext{
"É através da apercepção criativa, mais do que qualquer outra coisa, que o indivíduo sente que a vida é digna de ser vivida" (Winnicott, 1971a, p. 44). A criatividade e o brincar (como sinônimo do gesto espontâneo) são elementos da saúde. Sigmund Freud falou da saúde relacionando-a com a capacidade de amar e trabalhar e Winnicott acrescentou à questão o viver criativo. Se não encontramos o viver criativo de maneira predominante na vida, é frequente a existência de um esforço para existir baseado em um relacionamento com a realidade externa fundamentado na submissão ou no desejo do outro (como no falso self); pode ocorrer, também, de alguém ficar "preso", de forma tantalizante, à criatividade de um outro. Nestes casos teremos aquilo que é identificado como doença como o oposto da saúde.Podemos observar, na cultura contemporânea, pessoas que adoeceram pelo fato de estarem demasiadamente presas na realidade objetivamente percebida e que perderam o contato com o mundo subjetivamente concebido e, por consequência, com o viver criativo.

4 Romance de formação é um gênero em que se narra a trajetória de um personagem desde sua infância ou adolescência até uma fase mais madura.
} 
aborda, entre outros temas, a sabedoria dos mais velhos, o amor romântico e a literatura, um aluno me disse que não confiava nas pessoas mais velhas. Seu argumento era: "com tantos casos de pedofilia, de abusos sexuais, não é possível confiar cegamente nos mais velhos." Aquela fala parecia encontrar alguma ressonância no grupo. Ora, sem confiança nos mais velhos - na professora mais velha - a aprendizagem não ocorre... Refletindo um pouco sobre o episódio, consideramos que o aluno tinha tido confiança suficiente para me dizer aquilo, pois sabia que seria acolhido e não enfrentaria uma reação negativa de nossa parte. Esses comentários nos levam a refletir sobre o ambiente que criamos juntos.

A fim de que os jovens se sintam confortáveis para expor seus comentários em grupo, é necessária a criação de um ambiente de confiança. Além dos jovens, são imprescindíveis os educadores, que comparecem na intersubjetividade interpessoal - há dois sujeitos frente a frente exercendo um para o outro -, embora uma responsabilidade especial caiba ao adulto - a função de reconhecer. Winnicott (1975) destacou essa função que pode ser desdobrada em dois níveis: o de testemunhar e o do refletir/espelhar, sendo que a segunda depende da primeira: o espelhamento que não inclua o autêntico testemunho não poderá efetivar a tarefa de reconhecimento, criando imagens falseadas e alienantes do self. Muitas vezes, cuidar é, basicamente, ser capaz de prestar atenção e reconhecer os alunos no que eles têm de próprio e singular, dando disso testemunho e, se possível, levando de volta ao sujeito sua própria imagem. É o que acontece toda vez que prestamos atenção a uma história contada pelo aluno ou a um comentário feito em sala de aula e devolvemos para ele algum aspecto de si que ele ainda não percebeu como seu. Um exemplo disso é quando devolvo à turma o que os alunos disseram a seus leitores muitas vezes à revelia, sem se darem conta...

É comum os alunos se surpreenderem com a própria capacidade de expressão, quando lemos algumas produções em voz alta. Isso aconteceu, por exemplo, quando uma jovem leu sua história sobre uma Rapunzel moderna, que, tendo sido encastelada por sua mãe, era muito ingênua em relação à realidade e se deixou seduzir e enganar na primeira oportunidade que teve de fugir. A Rapunzel moderna inventada pela jovem autora enfrentou uma gravidez indesejada na adolescência por não ter tido a malícia de perceber a sedução de um aproveitador. Depois da leitura do conto, quando comentamos sobre o quanto a proteção da mãe havia fragilizado aquela Rapunzel, a aluna nos contou que não tinha percebido o quanto tinha falado de si naquela história e decidiu revelar para os colegas que aquele era seu medo - o de ser tratada com excesso de proteção. Ela sempre se mostrou muito preocupada com a condição feminina, e isso apareceu em várias de suas produções escritas no ano. Mais tarde, veio a se tornar uma das fundadoras do coletivo feminista de seu ano. Um caso semelhante foi o de um aluno que, depois de ler seu conto fantástico ${ }^{5}$ para os colegas, notou que havia contado uma história em que o personagem principal se via dividido entre as várias opiniões do grupo, assim como ele costumava se sentir. Ao falar do outro, do estrangeiro, fala-se de si, mesmo que isso não apareça de maneira evidente à primeira vista. Embora as propostas escritas não sejam autobiográficas, ao final de um ano os próprios alunos percebem o quanto uma ficção pode ser verdadeira.

Esta modalidade de cuidados, de tão discreta, pode passar despercebida, mas sua falta pode ser bastante prejudicial para a instalação da autoimagem e da autoestima. Porque é discreta, pouco se nota, a não ser quando falta ou falha a disponibilidade deste cuidar silencioso que se resume a prestar atenção e responder na medida quando e se for necessário (FIGUEIREDO, 2009).

Além de prestar atenção ao adolescente, quando interpelamos, desafiamos, propomos questões, exercemos um cuidado. Nesta condição, despertamos uma exigência de resposta. Ao cha- 
mar alguém pelo nome, ao solicitar que o sujeito responda por sua pessoa, sua existência, chama-se o sujeito à fala. Essa função é tão importante quanto as funções de acolher e reconhecer os alunos. Ao chamar um aluno a se colocar em classe, a dar sua contribuição para o grupo, todo educador chama para a vida e exerce também aí uma função de cuidado importante.

O objetivo deste trabalho é como resgatar sentidos - e dar vazão ao potencial criativo dos jovens alunos - na escola?

Há um cuidado quando criamos um ambiente de confiança para que os alunos sejam capazes do que Winnicott denomina "o gesto espontâneo"6 (WINNICOTT, 2017), ou seja, o gesto pessoal criativo, surpreendente.

Em sala de aula, é possível oferecer sustentação, suporte para que os alunos se lancem com sua própria voz e se sintam potentes para dar sua contribuição criativa, lançando-se em voo livre com a confiança de que poderão contar com a continência que lhes proporciona experiências de transformação.

É o que observo quando anunciamos aos alunos a proposta de escrita e montagem de uma peça teatral em parceria com os colegas e professores de outras áreas. Todos os anos, ao anúncio da proposta, os alunos dizem-se incapazes de realizá-la, consideram-na impossível, mas confiam nos professores e na experiência acumulada por outras turmas, que já realizaram esse sonho coletivo na escola.

Temos uma preocupação em desenvolver as etapas do caminho para que, gradativamente, os alunos ganhem cada vez mais confiança em si e no grupo para finalmente se entregarem a um projeto coletivo de grande envergadura. Depois da desafiante experiência da peça teatral do grupo-classe, os alunos não mais hesitam em se entregar à composição de contos fantásticos a serem transformados em filmes ou a se lançarem na criação de textos autorais.

Também buscamos legitimar aqui a voz do professor num momento em que, imersos na cultura digital, incentiva-se excessivamente a prática do ensino à distância a partir da crença de que bastaria o contato do jovem com o objeto cultural - sem necessidade da mediação do professor - para que a aprendizagem ocorra. Mas em que outros espaços, além da sala de aula, é possível estar junto a tantas pessoas com visões distintas para conversar sobre literatura, arte, cultura, enfim, sem prescindir do corpo? A obra de arte levada à sala de aula está lá para instigar o pensamento, diferente do mero entretenimento. Para além de espaço de reprodução - que também o é -, a escola pode ser um espaço de criatividade por meio da troca, da reflexão compartilhada e expandida pelas várias vozes e interpretações que enriquecem a leitura da realidade. Alunos com diferentes habilidades leitoras podem ampliar a percepção a partir das falas dos colegas sobre um mesmo objeto.

Partindo do que eles apresentam, investigamos algo que escapa àquilo que se compreende como sendo trabalho do professor de Língua Portuguesa, mas que é comum à prática de todo educador. Afinal, como Luís Claudio Figueiredo afirma em Metapsicologia do Cuidado, atividades de cuidar fazem parte das obrigações dos profissionais da educação, e os saberes e práticas da

\footnotetext{
O bebê, no início da vida, passa a maior parte do tempo não integrado: a integração dos vários elementos sensório-motores acontece pelas ações da mãe como envolver o lactante, às vezes concretamente ("handling"), às vezes simbolicamente (parte do "holding"). De vez em quando, de um impulso, surge um gesto espontâneo, que é um potencial do self verdadeiro do bebê. A fonte do gesto espontâneo é, portanto, o self verdadeiro, que "provém da vitalidade dos tecidos corporais e de atuação das funções do corpo, incluindo a ação do coração e a respiração" (Winnicott,1979, pág. 136), sendo, no entanto um pouco mais do que o mero viver sensório-motor, pois já inclui uma noção tênue de limites do próprio corpo.O self verdadeiro só se torna uma realidade viva se a mãe responder adequadamente ao gesto espontâneo. Se, ao lidar com o bebê, a mãe substitui o gesto espontâneo do bebê por seu próprio gesto, o bebê se submete, e este é o estágio inicial do falso-self.
} 
psicanálise podem nos oferecer preciosos elementos para uma compreensão rigorosa do que está envolvido nesses cuidados (FIGUEIREDO,2009).

Uma prática de cuidado importante dos educadores é proteger as capacidades de reparação e de criação, às vezes danificadas, dar assistência e ensinar (novamente) a brincar ${ }^{7}$, tratando os jovens como agentes de transformação, capazes de serem mais do que meros reprodutores, apostando na vida e na esperança de construção de algo que não parece imediatamente possível.

Investigamos a potencialidade transformadora da experiência estética, que pode contribuir para a constituição de um mundo interior capaz de sustentar adversidades, frustrações, inquietações, comumente vividas pelos jovens dessa faixa etária. Nesse contexto, a mediação foi fundamental e visou a acolher empaticamente, ajudar os jovens a descortinarem novos sentidos para as mais diversas situações de vida, ampliando a capacidade interpretativa.

Como método, a partir da experiência vivida no cotidiano de sala de aula, selecionamos episódios que mostrassem possibilidades de trabalho com determinados objetos culturais, primordialmente poemas, narrativas, peças de teatro e filmes, e recorremos a um diário de vinhetas de situações em sala de aula. Escolhemos também amostras de produções de antigos alunos que permitissem ver como a elaboração de angústias se dá na escrita ou como eles fazem uso da escrita como meio maleável para o seu gesto criativo e autoral.

Os episódios que descrevemos e analisamos foram um Projeto de Estudo do Meio às cidades históricas de Minas Gerais, a leitura mediada de O apanhador no campo de centeio, de Salinger; e o projeto de leitura e criação de contos fantásticos a serem transformados em filmes.

Segundo Marion Milner (1952/1991), que observou que o material usado pelo artista tem o mesmo papel receptivo que o brinquedo na brincadeira das crianças, os adultos também brincam e necessitam de materialidades, meios plásticos - o que ela denomina meio maleável -, que se mostrem receptivos a seu gesto pessoal. O escritor Raduan Nassar parece concordar com Winnicott e Milner sobre a relação entre a arte e a brincadeira:

Há quem diga que a diferença entre o adulto e a criança está só no tamanho do brinquedo. Comecei a me perguntar num certo momento por que expor em público o meu brinquedo. $O$ que há de lúdico numa atividade você transfere para outra com certa facilidade, desde que você seja sujeito de seu trabalho. (NASSAR, 1996, p.39).

Junto aos adolescentes, procuramos ampliar sua reserva cultural e acolher o que eles tinham a oferecer. Também olhamos suas produções procurando enriquecer a descoberta do potencial da linguagem escrita, a fim de que eles se percebessem autores responsáveis pelo que expressavam em suas produções criativas. Como Perrotta (2014) afirma, procuramos reapresentar objetos culturais, de modo que os jovens pudessem, às vezes, refazer o caminho, vivendo o tempo da onipotência, tendo sustentadas suas frustrações diante do não saber, imprimindo suas marcas pessoais em sua expressão.

\footnotetext{
Winnicott afirma que é apenas no brincar que o homem, criança ou adulto, pode desfrutar de sua personalidade de forma integral. Segundo ele, o terapeuta traz o paciente de um estado em que ele não é capaz de brincar para um estado em que o é (Winnicott, 1971/1975, p. 63).

Ele escreveu: "É no brincar, e talvez apenas no brincar, que a criança ou o adulto fruem na sua liberdade de criação", e completa: "é no brincar, e somente no brincar, que o indivíduo, criança ou adulto, pode ser criativo e utilizar sua personalidade integral: e é somente sendo criativo que o indivíduo descobre o eu (self)." (Winnicott, 1971/1975,p.79-80).
} 
Considerando que o espaço potencial ${ }^{8}$ não está apenas "entre", pois ele é um espaço onde o sujeito está em transição, compreendemos que os sujeitos estão se constituindo e se reconstituindo permanentemente. Assim, sair da área de onipotência, e do princípio de prazer, é um trabalho infindável, propiciando uma aceitação crescente de frustrações e limites, ao mesmo tempo em que expande o espaço para a criação, o brincar e o senso de humor.

Cabe aos adultos oferecer aos jovens um repertório de jogo, disponibilizando tempo, espaço e meios expressivos para que os adolescentes possam encontrar possibilidades de estar com o outro e com ele se comunicar. Escrever, atuar, cantar, desenhar, dançar, fotografar... tudo isso tem potencial transformador.

Compreendemos, assim, a partir de Winnicott (1975), que o "viver criativo" requer a instalação do espaço potencial, um espaço vazio, acolhedor e estimulante, baseado em confiança. Essa confiabilidade é indispensável para a morada no corpo, a instalação dessa área do brincar (playground) e para que esse espaço seja preenchido com produtos criativos da onipotência infantil. A confiança deve ser confirmada pela capacidade de o objeto sobreviver à agressividade inerente ao "uso", o que inclui o não retaliar. É no espaço potencial que se formam os fenômenos e objetos transicionais, a primeira possessão "não eu" do bebê, e, em mais tarde, os diversos produtos da cultura. A resiliência do objeto, sua capacidade de sobrevivência e de não retaliação são as bases para o desenvolvimento da confiança. "...Talvez o maior cumprimento que podemos receber é se formos tanto encontrados quanto usados" (WINNICOTT, 1968b/1994, p.81).

Em "A experiência de confiar na clínica e na cultura", Figueiredo (2009) retoma a problemática da confiança e da desconfiança em Balint (1959), para quem, na saída do amor primário para as primeiras formas de relação de objeto propriamente ditas - pois no amor primário a relação com o ambiente é pré-objetal - constitui-se, simultaneamente, a condição para a confiança e para a desconfiança.

O conceito de thrill diz respeito aos momentos decisivos para a instalação da confiança primária. (...) O thrill das primeiras atividades lúdicas está associado tanto ao despertar pulsional quanto ao exercício de entrega ao objeto certo na hora certa: balanços, rodopios, galopes, cócegas, sustos, etc. propiciam experiências alternadas de tensão e distensão, excitação e relaxamento que sempre terminam no abraço seguro de adultos alegres, amorosos e protetores. Thrills fazem parte, assim, da "educação sentimental" dos humanos e da difícil tarefa de articular alguma desconfiança, o preço incontornável da separação e da autonomia, com a confiança básica no ambiente e nos objetos, sem o qual se adoece (FIGUEIREDO, 2009, p.79).

Pensamos que é isso que os jovens podem experimentar ao se lançarem em projetos criativos na escola. É o que ocorre quando chegam ao oitavo ano e se deparam com propostas desafiadoras em que vão descobrir, na experiência com a poesia, o conto, o teatro..., aptidões que até então estavam em estado latente neles, esperando o momento de eclodirem. É o que observamos, quando, numa viagem de Estudo do Meio a Minas Gerais, os jovens garimpam histórias, verdadeiras pedras preciosas com as quais compõem a joia de um teatro realizado coletivamente.

Para explicar a origem da experiência cultural, Winnicott remonta às primeiras relações mãe-bebê (Winnicott, [1958], 1975) quando o bebê ainda "não existe", sendo apenas uma continuação de sua mãe. Uma mãe suficientemente boa é aquela que está inteiramente sintonizada com as necessidades de seu bebê e promove nele a ilusão de ser o criador dos objetos de seu mundo. O holding (segurar) e o handling (cuidados corporais) são condições que permitem a integração, a personalização do bebê e a possibilidade de identificar o objeto. A essas funções acrescenta-se ainda a função espelho (o olhar de reconhecimento).

O espaço potencial é apresentado como uma terceira área da existência humana, entre a realidade psíquica (ou mundo interno) e o mundo real em que o indivíduo vive (ou mundo externo). Trata-se de um espaço de criação. O que irá definir a forma de utilização desse espaço são as experiências de vida que acontecem nos estágios primários da vida, sendo, portanto, muito variável.. Se a mãe for capaz de proporcionar ao bebê uma experiência favorável, todo e qualquer pormenor de sua vida constituirá um exemplo do viver criativo. 
A confiança nasce da entrega, sucedida pelo susto, pelo medo e pelo conforto recuperado. Esse jogo entre intensidades afetivas e conforto final é a essência do thrill e a base experimental necessária para a instalação da confiança primária, segundo Balint (1959).

Mais do que ir e vir do objeto, mais do que o holding da dependência absoluta, na experiência do thrill, o voo livre é tão essencial quanto o abraço seguro, inclusive porque ele contrapõe-se a um outro motivo de desconfiança: o de que o abraço seja um claustro, uma prisão (FIGUEIREDO, 2009, p.80).

Propostas educacionais que desconsideram o espaço potencial para a escuta e a manifestação do gesto pessoal dos jovens - propostas aparentemente espetaculares muitas vezes - não possibilitam o espaço necessário para o pensamento, para o gesto criativo. Pode haver uma oferta de estímulos muito acima da capacidade de assimilação, como o gesto da mãe intrusiva, que substitui o gesto do bebê pelo seu próprio. Se, por um lado, a oferta de referências culturais é fundamental para que os alunos tenham contato como o que já se produziu antes deles na cultura, o excesso de leituras e estímulos, sem mediação, pode não ganhar sentido. É semelhante ao que escritor português José Saramago descreve, no documentário Janela da Alma (2004):

Podemos ter no futuro, em bem pouco tempo, pequenos canais de televisão, o que seria notável do ponto de vista do entretenimento, da cultura, da informação... eu tenho cá minhas dúvidas... Mas vamos imaginar que eu recebesse em minha casa quinhentos jornais por dia... como é que eu posso ler quinhentos jornais por dia? E que conclusões tiro eu da leitura de quinhentos jornais por dia? Nem seria possível, nem eu não teria proveito nenhum se entrassem em minha casa esses quinhentos jornais.

O tempo para a reflexão, que se dá com o professor, pela conversa sobre um objeto cultural selecionado é fundamental. Métodos de ensino que desconsiderem o tempo para elaboração dos estímulos não favorecem o conhecimento.

Em sua crítica aos métodos de ensino, a psicanalista Marion Milner (1942) questiona o quanto esses métodos, ao penalizarem o não saber, acabam por dificultar o conhecimento da realidade psíquica, que, para ser vivido como processo, e alcançado, necessita do desenvolvimento da capacidade de tolerar a dúvida: "Talvez não seja nada encorajador aferrar-se a certezas, que interferem no aprendizado das experiências plenas (MILNER, 1942/1991, p. 26)".

A tolerância à dúvida, o uso criativo do conflito, também seria, segundo Milner, um dos aspectos que nos levaria à descoberta da vida interna, o que implica em tolerar o choque entre alguma forma de expressá-los pela simbolização da experiência:

Esta capacidade simbolizante que a mente possui, sua infinita habilidade para utilizar metáforas a fim de expressar realidades psíquicas, flui em uma torrente poderosa que tem muitas ramificações: o brincar imaginário à infância, a arte, os rituais simbólicos, a religião (MILNER, 1942/1991, p. 25).

A palavra é um meio privilegiado de expressão para a maioria de nós, que possibilita uma ponte entre nosso universo particular e o mundo. Mas como abrir esse espaço para o pensamento? Como manejar isso em sala de aula?

Um meio para se conhecer os alunos são as narrativas que eles criam. No início do ano letivo, proponho a criação de versões modernas para contos de fadas consagrados, e por essas histórias observo um tema recorrente: a violência. Balas perdidas provocam mortes em centros urbanos, e o desemprego leva pais desesperados a abandonarem os filhos. Personagens convivem com a ameaça de sequestros, estupros, pedofilia, cyberbullying, discriminação na escola ou na família em narrativas em que o "lobo mau" aparece como assediador ou traficante de drogas. Em 
algumas delas, os "patinhos feios" são adolescentes solitários, discriminados pelos pais ou pelos pares por sua orientação sexual ou pela transexualidade... Algumas belas adormecidas contemporâneas abdicam das relações amorosas ou do convívio social para se refugiarem na suposta segurança da vida virtual - de fantasias - nas redes sociais, sustentando imagens irreais de si. Os desfechos são trágicos: personagens femininos sofrem violência sexual ao tentarem um encontro amoroso ou o suicídio é a saída para os conflitos vividos pelos personagens.

Pensamos existir uma ressonância entre os temas abordados nas narrativas dos alunos e a cultura de modo mais amplo. Ideias veiculadas pelo jornalismo sensacionalista, pelas propagandas e pelo marketing permeiam as versões modernas dos contos, cujos personagens, desesperançosos, nas mais variadas situações de risco - desde relações sexuais desprotegidas em raves até vencidos por compulsões e adições - estão bem distantes de viverem um final feliz. Uma sociedade da competição e da imagem, do culto às celebridades, da cultura da visibilidade e do marketing pessoal revela, pelo avesso, as graves deficiências em mecanismos sociais de reconhecimento dos indivíduos em suas singularidades (FIGUEIREDO, 2009).

Compartilhamos alguns episódios que vivemos com os alunos e que ilustram como essa ressonância entre escola e cultura se apresenta na sala de aula. Uma turma de alunos, particularmente, trazia no histórico a formação de uma "irmandade", como eles a denominavam, um grupo que, pelas redes sociais, combinava agressões veladas a colegas na escola. Esses alunos agrediam colegas e professores virtualmente e mantinham, na escola, uma aparente boa convivência. O clima de rivalidade e violência era velado. Embora desconhecêssemos detalhes do histórico do grupo, não tardou para que alguns comentários em sala de aula, durante as discussões dos livros, dessem indícios do que havia ali. Eram falas como: "os Capitães da Areia" eram todos bandidos, era mesmo um milagre um bandido arranjar trabalho". Ou: "Esse personagem é negro, mas, apesar disso, é muito inteligente". Ainda: "a Dona Ester quer adotar um Capitão da Areia. Acho isso irreal, porque não dá pra adotar um ladrão." Esses comentários feitos sem nenhuma censura revelavam a violência a que os alunos pareciam ter se habituado. Falas assim, que têm sido naturalizadas por alguns deles, desafiam os educadores a pensarem maneiras de desconstruir preconceitos dessa natureza. Afinal, os adolescentes reproduzem discursos de maneira inconsequente, muitas vezes sem terem consciência de onde surgem, e os fenômenos de totalitarismo, como a irmandade criada por alguns deles, revelam uma forte necessidade de inclusão em ambientes e objetos capazes de sustentação e continência. São justamente os indivíduos mais desamparados que se sentem atraídos pelas promessas de pertencimento absoluto proferidas por líderes de "irmandades" ...

Essas situações do cotidiano da escola nos levam a refletir continuamente. Orientamo-nos pela escuta dos alunos para escolher objetos culturais, de modo que possamos promover a ampliação da reflexão sobre esses temas que aparecem no grupo. É comum que associemos um livro, um filme, uma peça teatral a que assistimos às discussões em sala de aula. Procuramos incluir essas referências às conversas com os alunos, oferecendo-lhes imagens, narrativas, que possam ajudá-los a ampliar a compreensão do que é abordado na escola. Sendo assim, não é apenas necessário que ampliemos nossa reserva cultural, de modo a flexibilizar nosso modo de pensar, como também é estimulante encontrar sempre novas referências culturais que possam dialogar com as questões contemporâneas que os jovens trazem para a conversa conosco e com os colegas.

Buscamos escutá-los com empatia, com o "tato" que o psicanalista húngaro Sándor Ferenczi descreve como um "sentir com" (FERENCZI, 2011, p.31). Procuramos suspender o julgamento moral, pois nossas resistências poderiam inibir a expressão das ideias dos alunos, e tentamos criar situações baseadas em experiências de autenticidade, tanto nossa quanto deles. Abandonamos também a onipotência de tudo saber, mantendo-nos abertos para aquilo que pode emergir na relação. 
Essa atitude de compreensão, que pode dar uma "impressão de bondade", mas que provém da reflexão consciente, é uma "compreensão analítica" (FERENCZI, 2011, p.33). Assim como afirma Ferenczi, para quem "o analista deve prestar-se às vezes ao papel de "João teimoso" em que o paciente exercita seus afetos de desprazer" (FERENCZI, p.35), procuramos escutar os alunos com paciência e tolerância, sem juízo moral, buscando uma atitude compreensiva. No decorrer do tempo, essa postura leva a uma maior confiança dos alunos. Também procuramos interpretar o que eles falam mais com um caráter de proposição do que de uma afirmação indiscutível.

"Sentir com", nos observar e, por fim, elaborar uma reflexão sobre o que experimentamos com a turma nos ajuda a conduzir o trabalho em sala de aula. A paciência que temos com os alunos não equivale, no entanto, a ceder sem resistência. Também não há sentimentalismo, e fazemos cortes e damos certo contorno aos jovens quando vemos necessidade. Oferecemos nossa escuta empática, procurando "sentir com" eles seus humores, mas também nos atemos com firmeza à nossa posição ditada pela experiência em sala de aula. Esse "sentir com", ou seja, esse fator subjetivo também é muito diferente da mera "intuição", uma vez que existe uma apreciação consciente da situação dinâmica (FERENCZI, p.41). A partir dessa escuta empática, entendemos que seja nosso papel apresentar referências para além das já conhecidas ou dialogar sobre aquelas que os alunos trazem, de modo a ajudá-los a enriquecer e a tornar mais complexa a compreensão da realidade.

Há muito tempo, um aluno muito ensimesmado, quieto, considerado "deprimido" pela falta de engajamento nas atividades em todas as disciplinas, chegou até o oitavo ano. Ele costumava ficar em silêncio durante as aulas, não produzia textos claros em nenhuma disciplina, nem conseguia redigir respostas dissertativas nas avaliações. Ficamos surpresos ao ver que esse aluno só conseguia se expressar pela poesia. Era o único gênero textual com o qual se envolvia. Foi a partir de seus poemas que percebemos a agudeza e a profundidade dos sentimentos desse aluno, um jovem muito sensível, capaz de tocar em assuntos difíceis por meio de poemas, que tratavam da dor e da solidão. Não era comum que os alunos da turma tratassem desses temas... Por meio dos poemas, pudemos sentir um pouco da solidão que ele experimentava. Foi muito comovente para todos vê-lo lendo um poema no sarau do fim do ano.

Os poemas e textos ficcionais produzidos pelos alunos revelam, como uma tábua projetiva, estados emocionais inconscientes. Foi o caso de outro aluno tido como pouco sociável e com muita dificuldade para fazer amigos que, no final do ano, produziu um conto fantástico no qual um gato se via num mundo de cachorros e se sentia solitário até encontrar seus pares. Esse aluno só conseguiu produzir esse conto quando já tinha amigos na turma.

Uma jovem, na segunda semana de aula, nos entregou um maço de narrativas de sua autoria. Seus textos apresentavam traços de estilo típicos dos que já muito cedo manifestam um pendor para a literatura. Numa de suas narrativas, ela contava a história de um casal que discutia muito e "fazia brindes com Rivotril" ao som de "Back to black", da cantora inglesa Amy Winehouse. Seus textos tinham sempre um tom mais grave do que as histórias produzidas pela turma. Ela manifestava sua indignação em relação à realidade por meio da ficção que criava, e suas narrativas tratavam, quase sempre, de drogas, violência física e abuso.

Observamos que a criação poética e ficcional permite tanto a elaboração de conteúdos inconscientes quanto a transformação do sujeito, que pode expressar por meio dos textos ideias que às vezes Ihe parecem escapar à revelia. 
O escritor moçambicano Mia Couto ${ }^{10}$ nos diz que ensinar a ler é sempre ensinar a transpor o imediato. É ensinar a pensar no sentido original da palavra "pensar", que significa "curar" ou "tratar" um ferimento. Temos de repensar o mundo no sentido terapêutico de o salvar das doenças pelas quais padece. A palavra "ler" vem do latim legere e queria dizer "escolher". Era isso que faziam os antigos romanos quando, por exemplo, selecionavam entre os grãos de cereais. A raiz etimológica está bem patente no nosso termo "eleger". Ora, o drama é que hoje estamos deixando de escolher. Estamos deixando de ler no sentido da raiz da palavra. Cada vez mais somos escolhidos, cada vez mais somos objeto de apelos que nos convertem em números, em estatísticas de mercado. A nossa tentação é quase sempre maniqueísta. A visão simples que separa os "bons" dos "maus" é sempre a mais imediata. Quanto menos entendemos, mais julgamos.

Os adolescentes querem descobrir o mistério da vida e da morte (SAFRA, 2018). Eles têm a tarefa de encontrar companhia afetivo-sexual e sentem essa tarefa como uma questão de conquista e competência. Somos sustentados pela nossa rede afetiva, pois precisamos do abraço mencionado por Winnicott (1975). Estamos sustentados pelos valores que nos são caros e somos capazes de atravessar situações difíceis graças a esses valores. "Quando um jovem se suicida porque perdeu uma namorada, por exemplo, costumamos pensar que ele o fez porque perdeu seu objeto de afeto. No entanto, hoje isso acontece porque ele perdeu a possibilidade de ter esperança de um abraço num mundo sem sentido." (Safra ${ }^{11}$, 2018).

Concordamos com Safra (2018), quando diz que interpretar os adolescentes não tem muito efeito. Segundo ele, a busca de um sentido para a experiência aponta para o futuro. Na pós-modernidade, quando tudo se relativiza e ocorre a "digitalização da realidade" (idem), ao compartiIhar uma obra literária em sala de aula, num ambiente de confiança, abrimos possibilidades para o vir a ser. Quanto mais conseguimos preservar a autenticidade na minha relação com os adolescentes, mais eles se envolvem e contribuem com o gesto autêntico deles. Os adolescentes estão hipersensíveis às questões fundamentais da condição humana e precisam ter esperança de que poderão contar com adultos para que este mundo ganhe um sentido. Se o mundo renasce com o nascimento de uma criança, como disse Guimarães Rosa ${ }^{12}$, com cada adolescente o mundo ganha ruptura e novos horizontes (Safra,2018). Uma boa síntese que um aluno fez da leitura compartilhada de $O$ apanhador no campo de centeio no espaço potencial da sala de aula: "o próprio livro é uma forma de Holden (narrador-personagem) lidar com tudo isso que ele viveu. Ele resolveu contar sua experiência para outros e, para isso, escreveu um livro". E não é justamente para isso que escrevemos?

\section{REFERÊNCIAS}

BAKHTIN, M. Estética da criação verbal. São. Paulo: Martins Fontes, 2003. p.261-306.

BALINT, M. (1959) Thrills and Regressions. London, England: H. Karnac (Books) Ltd, 1987.

CANDIDO, A. (1989) Direitos Humanos e Literatura. São Paulo: Ed. Brasiliense.

10 Mia Couto. “Quebrar armadilhas". In: Couto, Mia. E se Obama fosse africano? e outras interinvenções/Ensaios”. Lisboa: Editorial Caminho, 2009. Disponível em: <http://files.lerO.webnode.pt/2000000510543c0643c/E\%20Se\%200bama\%20Fosse\%20 Africano_\%20-\%20Mia\%20Couto.pdf>. Acessado em 23 de abril de 2018.

11 Informação verbal. Conferência do psicanalista Gilberto Safra intitulada "Modalidades psicopatológicas do adolescente e jovem na atualidade", apresentada no Teatro da UNIP, em 12 de maio de 2018.

12 "Um menino nasceu. O mundo tornou a começar." Essa fala foi proferida pelo personagem Riobaldo, do romance Grande Sertão Veredas, do escritor brasileiro João Guimarães Rosa, publicado em 1956. O jagunço Riobaldo atravessava os ermos da caatinga, quando ouviu os gemidos de parturiente que vinham de um misérrimo casebre, enterrado na solidão. A mulher estava só, com suas dores e seu ventre inchado. Naquela noite o jagunço não teve escolha, a força irresistível da vida o converteu em parteira. Foi assim que, pelas mãos de um jagunço, no fundo do sertão, mais uma criança nasceu. 
FERENCZI, S. (2011) "Elasticidade da técnica psicanalítica". In: Obras Completas. Vol. IV. São Paulo: Martins Fontes.

FIGUEIREDO, L. C. (2009) As diversas faces do cuidar: novos ensaios de psicanálise contemporânea. São Paulo: Escuta.

MILNER, M. (1952/1991) A loucura suprimida do homem são. Rio de Janeiro: Imago.

NASSAR, R. (1996) Cadernos de Literatura Brasileira. São Paulo: Instituto Moreira Salles, n. 2. Setembro.

PERROTTA, C. M. (2014) Processos criativos no espaço terapêutico da escrita: um diálogo com D.W. Winnicott, Clare Winnicott e Marion Milner. Dissertação de doutorado em Psicologia Clínica. Orientadora: Elisa Maria de Ulhôa Cintra. Pontifícia Universidade Católica de São Paulo. PUC-SP.

ROJO, R. (2004) Letramento e capacidades de leitura para a cidadania. São Paulo: SEE: CENP. Recuperado de: <http://www.academia.edu/1387699/Letramento_e_capacidades_de_ leitura_para_a_cidadania>. Acessado em: 1 de maio de 2018.

SALINGER, J.D. (2015) 0 apanhador no campo de centeio. Trad. Álvaro Alencar, Antonio Rocha, Jório Dauster, Rio de Janeiro, Editora do autor.

WINNICOTT, D.W. (1971a). Playing and Reality. London: Tavistock.

WINNICOTT, D. W. (1967/1975). "A localização da experiência cultural", in: WINNICOTT, D. W. O Brincar e a Realidade. Rio de Janeiro: Imago, pp. 133-143.

WINNICOTT, D.W. (1979). O ambiente e os processos de maturação. Porto Alegre: Artes Médicas.

WINNICOTT, D. W. (1964-1968/1994). "O jogo do rabisco". In C. Winnicott, R. Shepherd, \& M. Davis (Orgs.). Explorações psicanalíticas D.W. Winnicott (pp. 230-243). Porto Alegre: Artes Médicas.

WINNICOTT, D. W. (2017). O gesto espontâneo. São Paulo: Martins Fontes.

Janela da Alma - documentário. Dir.: João Jardim e Walter Carvalho, Brasil, 2012 